\title{
Espaço e tempo na agroindústria canavieira de Pernambuco
}

\author{
MANUEL CORREA DE ANDRADE
}

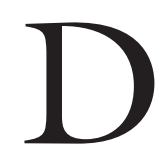

URANTE VÁRIAS décadas, até meados do século XX, quando foi suplantado por São Paulo, Pernambuco foi o principal produtor nacional de açúcar. Até então, seus concorrentes mais importantes - Bahia e Rio de Janeiro - não conseguiram ultrapassá-lo. Entretanto, logo após foi suplantado por Alagoas, e continuou perdendo importância, na última década do século XX, como pode ser observado pelo quadro 1 .

Nesse quadro são apresentadas a produção brasileira, e as das regiões Centro-Sul e Nordeste nas safras de 1988 a 1999. Observa-se que enquanto a produção da região Centro-Sul correspondia a $64,8 \%$ da produção nacional e a do Nordeste $34,9 \%$, na safra $1998-99$ passaram a $85,9 \%$ e 14,9 , respectivamente, mostrando perda considerável para a última.

$\mathrm{Na}$ discriminação da produção de açúcar por estados, observa-se que na safra 1988-89 Pernambuco ainda não havia sido suplantado por Alagoas atingindo $45 \%$ da produção regional contra $38,7 \%$ da produção alagoana. Na safra de 1998-99, porém, esse percentual correspondeu a apenas $37,3 \%$ da produção nordestina, enquanto Alagoas participou com $47 \%$.

No período referido a safra nordestina apresentou sensíveis quedas de produção durante anos de seca (1993-94 e 1998-99). Além da seca, a queda da produção estadual e regional foi causada pela dificuldade em competir com os custos de produção do Centro-Sul sobretudo depois da extinção Instituto do Açúcar e do Álcool (IAA) e da política governamental de subsídios.

Atualmente a economia canavieira em Pernambuco encontra-se em retrocesso. Numerosas usinas encerraram suas atividades industriais, com forte repercussão na atividade agrícola, por desemprego no meio rural e avanço dos movimentos sociais de trabalhadores rurais (MST e FETAPE, sobretudo), aliados às ações promovidas pelos trabalhadores rurais junto à Justiça do Trabalho e ao pagamento das indenizações por tempo de serviço com terras. Assim, pela lentidão da ação do Incra frente às invasões, o processo de esfacelamento das propriedades rurais avança com firmeza. 
Quadro 1

Produção brasileira de cana-de-açúcar no período 1988-1994

\begin{tabular}{|c|c|c|c|c|c|c|c|}
\hline $\begin{array}{c}\text { País/Região/ } \\
\text { Estado }\end{array}$ & 1988/89 & $1989 / 90$ & \multicolumn{2}{|c|}{$1990 / 91$} & $1991 / 92$ & $1992 / 93$ & $1993 / 94$ \\
\hline Brasil & 8.070 .212 & 7.264 .180 & \multicolumn{2}{|c|}{7.426 .310} & 8.658 .361 & $1 \quad 9.330 .565$ & 9.359 .447 \\
\hline Centro-Sul & 5.253 .242 & 4.154 .749 & \multicolumn{2}{|c|}{4.534 .023} & 5.834 .774 & 6.142 .717 & 7.008 .673 \\
\hline Nordeste & 2.816 .970 & 3.109 .430 & \multicolumn{2}{|c|}{2.892 .288} & 2.823 .588 & 3.187 .848 & 2.350 .774 \\
\hline Maranhăo & 30.260 & 26.705 & \multicolumn{2}{|c|}{25.082} & 19.918 & 13.485 & 12.158 \\
\hline Piauí & 0 & 0 & \multicolumn{2}{|r|}{0} & & 0 & 0 \\
\hline Ceará & 40.952 & 37.522 & \multicolumn{2}{|c|}{35.341} & 31.141 & 24.837 & 15.764 \\
\hline R. G. Do Norte & 103.883 & 114.166 & \multicolumn{2}{|c|}{91.570} & 103.290 & 131.079 & 75.475 \\
\hline Paraíba & 107.838 & 112.687 & \multicolumn{2}{|c|}{104.886} & 86.748 & 85.335 & 42.481 \\
\hline Pernambuco & 1.258 .746 & 1.350 .866 & \multicolumn{2}{|c|}{1.215 .145} & 1.162 .683 & 1.309 .642 & 955.366 \\
\hline Alagoas & 1.090 .095 & 1.281 .457 & \multicolumn{2}{|c|}{1.234 .987} & 1.243.282 & 1.438 .052 & 1.061 .015 \\
\hline Sergipe & 86.336 & 93.832 & 10 & 520 & 61. & 67.983 & 45.285 \\
\hline Bahia & 96.073 & 87.727 & & 256 & 112. & 117.167 & 140.128 \\
\hline & & Per & 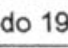 & 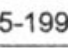 & & & \\
\hline $\begin{array}{c}\text { País/Regiäa/ } \\
\text { Estado }\end{array}$ & $1994 / 95$ & 1995 & & & $96 / 97$ & $1997 / 98$ & $1998 / 99$ \\
\hline Brasil & 11.897 .937 & 12.695 & 289 & 13.6 & 26.724 & 14.972 .441 & 17.715 .508 \\
\hline Centro-Sul & 8.516 .714 & 9.31 & 505 & 10.4 & 23.413 & 11.366 .517 & 15.074 .906 \\
\hline Nordeste & 3.381 .223 & 3.379 & 784 & 3.2 & 03.311 & 3.606 .924 & 2.640 .602 \\
\hline Maranhão & 25.017 & & 680 & & 25.337 & 8.599 & 14.041 \\
\hline Piauí & 0 & 0 & 0 & & 0 & 0 & 0 \\
\hline Ceará & 15.584 & & .935 & & 23.080 & 21.801 & 12.801 \\
\hline R. G. Do Norte & 137.075 & 126 & 317 & & 28.420 & 155.033 & 127.945 \\
\hline Paraíba & 66.581 & & .778 & & 79.341 & 105.395 & 61.911 \\
\hline Pernambuco & 1.345 .200 & 1.357 & 151 & 1.2 & 22.838 & 1.247 .766 & 984.001 \\
\hline Alagoas & 1.560 .568 & 1.543 & 349 & 1.5 & 22.167 & 1.837 .888 & 1.242 .300 \\
\hline Sergipe & 57.855 & & 657 & & 60.493 & 73.384 & 46.001 \\
\hline Bahia & 171.134 & 153 & 175 & & 38.010 & 151.322 & 143.235 \\
\hline
\end{tabular}

Fonte: MICT, AIAA, SINDALCOOL, SINDAÇUCAR/PE, SIND/AL, ASSUCALAL e Unidades Produtoras

No território pernambucano a cana-de-açúcar é cultivada na chamada Mesorregião da Mata, que compreende uma estreita faixa de terra paralela ao litoral, situada entre o rebordo oriental do Maciço da Borborema e o mar. Em alguns pontos ela apresenta encostas relativamente íngremes (figura 1), em forma de colinas mamelonares, e em outras, na forma de tabuleiros arenosos e planos. É cortada por rios de pequena extensão, que nascem nas encostas da Borborema e se dirigem para o oceano. Tais rios, apesar de serem permanentes, têm regime muito irregular: grande variação do débito entre a estação chuvosa - de maio a 
julho - e a estação seca - de agosto a abril. Enquanto nos alto e médio cursos eles são bastante encaixados, formando vales profundos, no baixo curso correm em planícies aluviais pleistocênicas e holocênicas, formando várzeas baixas e freqüentemente inundáveis. Muitas vezes estas várzeas, de solos turfosos, necessitam ser drenadas para que se possa culturar a cana.

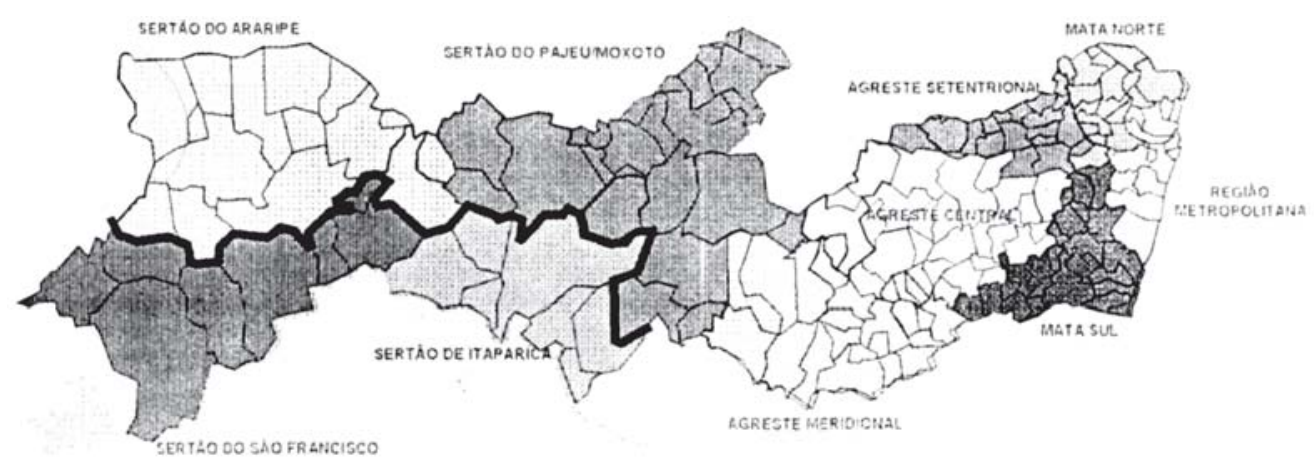

Figura 1 - Pernambuco: Regiões de desenvolvimento

Os solos nas encostas são em geral lateríticos, chamados de "barro vermelho"; nos tabuleiros são silicosos; nas várzeas, aluviais, altamente argilosos, denominados localmente de "massapé", tipo de solo muito enaltecido por Gilberto Freyre (1937) como típico da região.

O clima da área é quente durante todo o ano, o que facilitou a difusão da cultura da cana-de-açúcar. Caracteriza-se por ter duas estações bem definidas, com chuvas frontais de outono-inverno mais concentradas, e chuvas de convecção no período mais quente do ano, em dezembro e janeiro, as chamadas localmente de "chuva do caju". A umidade, porém, varia de acordo com as taxas pluviométricas, que diminuem do litoral para o interior (figura 2) e do Sul para o Norte. Nas bordas da Borborema estas taxas aumentam em função da posição do relevo, que provoca a ascensão da massa de ar, a condensação e as chuvas orográficas.

Assim, uma combinação de fatores físicos e humanos provocou o desenvolvimento da cultura da cana-de-açúcar e a sua expansão durante quatro séculos, plasmando uma sociedade e uma civilização. Entre os fatores de ordem física podemos salientar a posição geográfica, ou seja, a distância do mercado europeu em relação a outras áreas do país, as condições de solo e de clima e o sistema da agricultura açucareira, trazida das ilhas do Atlântico na ocasião em que o capitalismo comercial presidia à expansão européia pelos continentes que iam sendo “descobertos” e conquistados (Prado Júnior, 1942).

Hoje, tais condições mudaram em face da formação de um forte centro de consumo na região Sudeste do país e da proximidade do mercado platino. Além 
disso, o maior poder político dos estados do Sudeste diminuiu a influência política e econômica do Nordeste desde os meados do século XIX, devendo ainda serem consideradas a introdução e a evolução de tecnologias mais avançadas, incluindo a difusão do uso da irrigação dos canaviais.

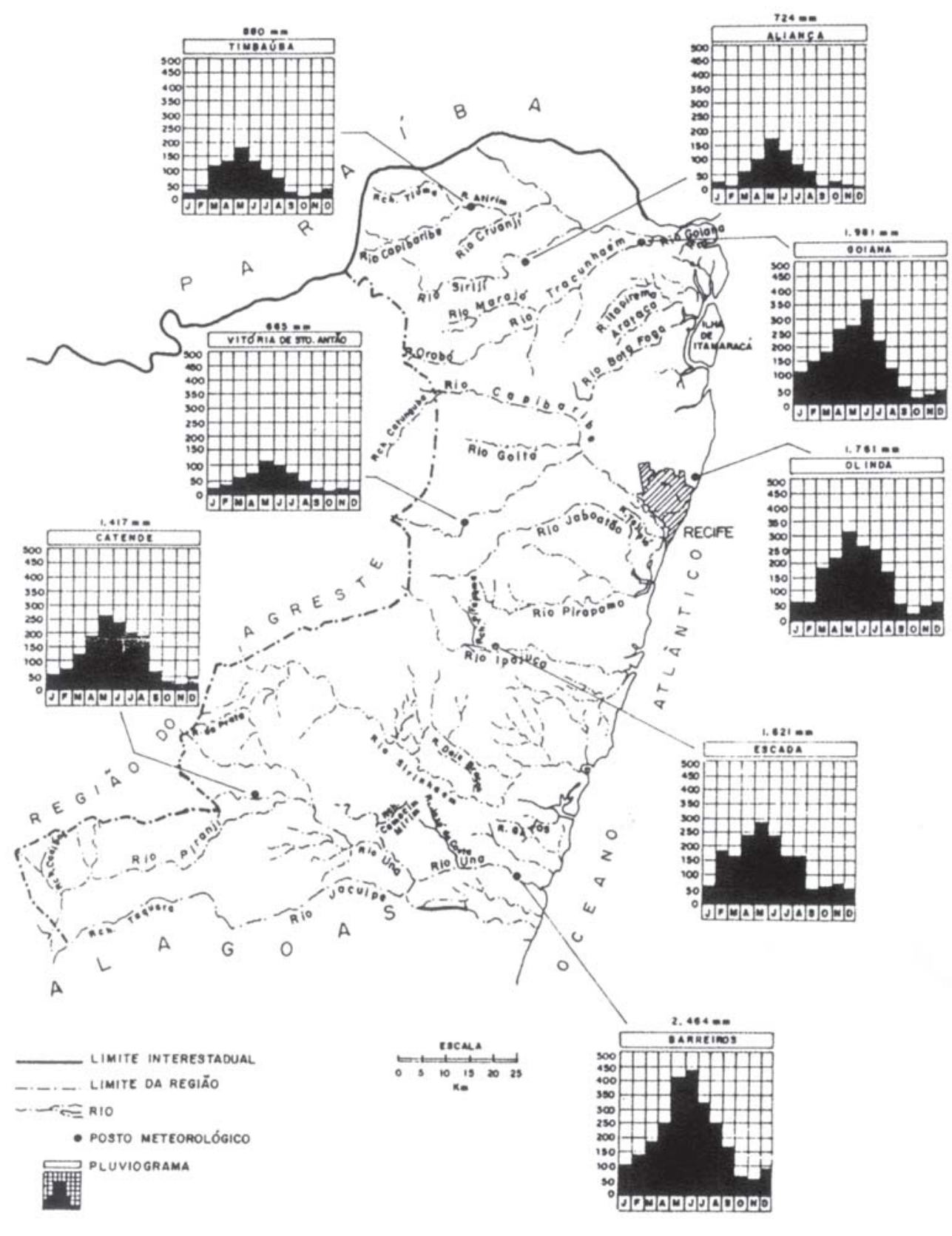

FONTE: C. N.G

Figura 2 - Hidrografia e pluviosidade da região da Mata Pernambucana 


\section{Do banguê à usina}

A formação econômica e social do Nordeste foi comandada por uma sociedade que ainda apresentava, em Portugal, características de domínio de uma casta guerreira, formada pelo rei e pela nobreza ibérica, mas já altamente infiltrada pela influência burguesa de comerciantes judeus, italianos e de outras áreas do continente europeu. Por ocasião do povoamento das ilhas do Atlântico e do Brasil nos séculos XV e XVI, os reis de Portugal estavam profundamente comprometidos com a atividade comercial que enriquecia a sua corte, em Lisboa (Azevedo, 1947).

Frustrada a tentativa de formação de um império na Índia, na quarta década do século XVI os portugueses iniciaram o processo de colonização, a plantation açucareira que iria substituir o extrativismo do pau brasil e de outros produtos de menor valor. Celso Furtado (1959), em livro hoje clássico, já chamava a atenção para o fato de o Brasil ter sido palco de uma grande experiência de investimento de capitais na atividade agrícola, ao contrário do que ocorria na Europa, onde se aplicava como fatores de produção na agricultura quase que apenas a terra e o trabalho.

A plantation, iniciada em Pernambuco e na Bahia na primeira metade do século XVI, foi dedicada sobretudo à cana-de-açúcar, ativando o desmatamento e implantando os engenhos que fabricavam o açúcar bruto, a rapadura e a aguardente. Movidos no inicío à força humana, posteriormente os engenhos utilizaram a tração animal - bois e éguas - ou a água. Havia engenhos dos mais diversos portes e importância, convivendo com os chamados engenhos reais e as engenhocas. Em geral, os proprietários eram sesmeiros ligados aos donatários das capitanias e recebiam o financiamento de comerciantes europeus, sobretudo de judeus sefarditas que haviam sido expulsos de Portugal e se instalado na Holanda. Daí a ação holandesa, invadindo o Nordeste do Brasil quando entrou em guerra com a Espanha, dominando a região de 1580 a 1640, para garantir os capitais investidos e os lucros advindos do comércio açucareiro.

A sociedade daí advinda foi estruturada em classes, de forma rígida, ficando no ápice a nobreza, dita da terra, os grandes comerciantes e os altos funcionários reais que detinham o poder econômico e político. Essa classe era seguida de outra, denominada média, formada por sitiantes, pequenos proprietários e prestadores de serviços, e de uma classe baixa, constituída por pessoas pobres que também prestavam serviços, mas de forma ocasional, muitas vezes gratuitos. Era a gente "sem eira nem beira", como se dizia, então. Finalmente havia a grande massa de escravos, em sua maioria africanos adquiridos no Continente negro mediante escambo com fumo e aguardente, trazidos pelos tumbeiros para o país, onde eram comercializados. Nos primeiros séculos, ainda havia escravos indígenas, os chamados "negros da terra"; após a sua libertação, ficavam eles aldeados, prestando serviços gratuitos ou quase gratuitos aos proprietários de terra. 
O desenvolvimento da cultura da cana e da produção de açúcar transposto do Brasil para as Antilhas após a expulsão dos holandeses do Nordeste, provocou uma melhoria nas técnicas de produção e na qualidade do produto. $\mathrm{O}$ fato causou um impacto sobre a região que continuou, até o início do século XIX, a cultivar a cana crioula, a usar a mão-de-obra manual - o arado só foi introduzido em meados do século XIX - e a produzir o açúcar bruto, de baixa qualidade.

As inovações em escala internacional introduzidas no século XIX determinaram a necessidade de modernização da indústria açucareira, dando margem ao programa imperial de implantação de engenhos de maior produção. Assim, a partir de 1874 foram implementadas melhorias nos banguês, visando à produção de açúcar branco e demerara, surgindo então as fábricas de maior capacidade de produção. Quando eram de propriedade particular, chamavam-se usinas; quando de empresas comerciais, geralmente estrangeiras, denominavam-se engenhos centrais. O que distinguia umas das outras era que as usinas, sendo de propriedade de antigos senhores de engenho e de parentes e vizinhos associados, não separavam a produção da industrialização da cana e utilizavam a mão-de-obra escrava, enquanto os engenhos centrais, subsidiados e com garantias de juros do capital aplicado pelo governo, tinham restrições quanto à posse de terras para a cultura da cana e à utilização da mão-de-obra escrava. A produção da cana a ser industrializada nos engenhos centrais era feita por proprietários de terra, antigos senhores de engenho que a vendiam ao engenho central, comprometendo-se a fornecer cotas anuais. Esses proprietários de engenho que desmontavam a sua indústria, eram chamados de fornecedores de cana, substituindo os banguezeiros.

Os engenhos centrais instalados em Pernambuco a partir de 1884 tiveram pequena duração. Muitos deles foram vendidos a usineiros, sobretudo após a proclamação da República, face ao poder político que os chefes regionais passaram a exercer após a descentralização promovida pelo 15 de novembro.

Com o processo usineiro, como observar-se-á no próximo tópico, foram fundadas numerosas pequenas usinas, muitas delas com instalação de algumas máquinas que lhes permitia a produção do açúcar demerara. Eram chamadas de meios-aparelhos ou meias-usinas e, à medida que aumentavam a sua capacidade de produção, iam absorvendo os engenhos banguês que restavam e posteriormente também pequenas e médias usinas. Observou-se, então, que ao mesmo tempo em que diminuía o número de usinas em atividade, aumentava a produção de açúcar e de álcool.

Salienta-se ainda que o grupo dominante, formado com a colonização, teve a capacidade de se adaptar a cada momento histórico, continuando até hoje no controle da produção açucareira regional, expandindo-se até em outros estados da Federação e formando uma oligarquia política que manteve por muito tempo o controle do estado. 


\section{Médias e grandes usinas: os grupos econômicos}

O processo de extinção dos engenhos banguês e a sua substituição por usinas e engenhos centrais iniciado no último quarto do século XIX foi lento a princípio. Posteriormente houve uma tal aceleração, que em 1914 já colocara em funcionamento cerca de 56 usinas. Os engenhos centrais foram fechados ou transformados em usinas após a proclamação da República e produziram, na safra 1913-14, 2.403.000 t de açúcar, ou 40.050 sacas de $60 \mathrm{~kg}$. A média de produção por usina foi de 42.910 sacas e as maiores safras foram as das usinas Catende (130 mil t), Cruanji e Tiúma (100 mil t cada uma).

Em 1934, 20 anos depois, apesar de a crise dos anos 20, o número de usinas elevou-se a 66, indicando certo dinamismo no processo usineiro. Nesse período de crise, porém, acentuaram-se as disputas entre usineiros, fornecedores de cana e lavradores, levando o governo a criar o Instituto do Açúcar e do Álcool para disciplinar e regionalizar a agroindústria, além de promulgar leis que regulamentavam as relações entre os grupos sociais integrantes do processo (Carli, 1992; Andrade, 1989). A produção total do ano foi de 3.219 .124 sacas de $60 \mathrm{~kg}$, correspondentes a 48.744 sacas por usina. À época, numerosas usinas não possuíam destilarias de álcool e vendiam melaço para aquelas mais próximas ou continuavam a produzir aguardente em suas antigas destilações; o melaço era também utilizado na alimentação de animais.

Com a adoção de uma política governamental mais unificada, o número de usinas reduziu-se a 53, mas dada à importância conferida à produção de álcool, foram instaladas duas destilarias desvinculadas de usinas, uma delas pelo governo federal, com produção bastante expressiva.

As usinas produziram, na safra 1953-54, 8.985.242 sacas de $60 \mathrm{~kg}$, o equivalente a 169.532 sacas por usina. A diferença de capacidade entre elas era acentuada: as três maiores safras foram registradas nas usinas Central Barreiros (733.400 sacas), Catende (676.024) e Santa Teresinha (535.384), enquanto as menores em Regalia (1.720 sacas), Nossa Senhora de Lourdes (6.000) e Crauatá (6.657). No que diz respeito à produção de álcool, que foi de 77.361.628 litros, a Destilaria Central Presidente Vargas, estatal, contribuiu com 19.795.068 litros, ou $25,58 \%$ da produção do estado.

Neste período, pequenas usinas em crise encerraram as suas atividades, e foi travada uma luta entre três grupos econômicos estaduais: o da Central Barreiros, liderado pelo ex-governador, ex-ministro e ex-vice-presidente da República, Estácio Coimbra; o de Catende, que durante mais de um decênio foi a usina de maior produção de açúcar e álcool do país, liderado por Antônio Ferreira da Costa Azevedo, conhecido pelo apelido de Tenente; e o de José Pessoa de Queiroz, da usina Santa Teresinha, apoiado por uma família de comerciantes e industriais, influente no setor açucareiro, na indústria de fiação e tecelagem e na imprensa. 
A safra de 1973-74, resultou na produção de apenas 38 usinas, com cerca de 19.004 .115 sacas de açúcar de $60 \mathrm{~kg}$. Nenhuma delas chegou a atingir um milhão de sacas, fato que também ocorreu ainda durante a década 71-80. As que apresentaram maiores produções, superiores a 700 mil sacas, foram Central Barreiros, Catende, Central Olho D'Água, Matari, Petribu e Santa Teresinha, destacando-se a Santa Teresinha pela maior produção, com 855.150 sacas. A média por usina foi de 500.108 sacas, bastante elevada para o período. As pequenas e médias usinas haviam sido eliminadas devido à intervenção do governo federal, implantando programas que as modernizaram, abrindo perspectivas para a ampliação de algumas.

Com a criação do Proálcool, as usinas dispuseram de recursos para ampliar as suas atividades industriais, expandindo a cultura da cana até por áreas ecologicamente pouco favoráveis. Surgiram destilarias autônomas, desvinculadas de usinas. As destilarias governamentais foram desativadas a fim de fortalecer as atividades de grupos econômicos privados. No período de domínio do governo militar, a agroindústria continuou a se expandir graças aos subsídios concedidos. No setor açucareiro, que atualmente enfrenta uma forte crise, algumas usinas e destilarias estão vivendo seus últimos momentos. Algumas delas suspenderam a moagem na safra de 1998-99, como ocorreu com a Central Barreiros, a Nossa Senhora de Lourdes e a Santo André. Grande parte da matéria-prima produzida foi destinada à produção do melaço, que alcançou 7.511.658.313 t (figura 3).

Na safra 1998-99 a queda de produção foi ainda mais acentuada devido à crise financeira que atingiu o setor, ligado que está à crise nacional, dependente da política recessiva governamental. Outro aspecto que acentuou essa queda foi a grande seca que assolou o Nordeste, atingindo também a região da Mata, tradicionalmente úmida. Como mencionado, numerosas usinas estão vivendo seus momentos finais, sendo vendidas a grupos de outras áreas ou transferidas para o Sudeste - sobretudo Minas Gerais - e para o Centro-Oeste.

A agroindústria açucareira pernambucana permaneceu isolada de interferência de capitais do Sudeste e do exterior até os dias atuais, fato que ocorreu também, com grande intensidade, no setor têxtil e de mineração, que estiveram sempre sob o controle da oligarquia açucareira. Implantada no século XVI, manteve o controle político e econômico do estado até quase os nossos dias. Famílias tradicionais vêm controlando engenhos banguês, usinas e destilarias, contando sempre com o apoio governamental para subsidiar e financiar os seus empreendimentos. No governo republicano, os usineiros conseguiram leis que lhes facilitaram empréstimos a juros baixos e perdão de dívidas. O governo federal foi também generoso com os grupos nordestinos - fato que ocorreu também em outros estados -, fornecendo créditos e avalizando empréstimos em dólares, no exterior. Foi neste período que oito usinas obtiveram esses empréstimos, com o aval do Banco do Estado de Pernambuco. Deixando de quitar suas dívidas, levaram o 
Bandepe a honrar os compromissos assumidos e entrar em uma forte crise que o levou à privatização, em 1998.

Acreditamos que, em função do aprofundamento de pesquisas de história econômica, estudos deveriam ser realizados a respeito de alguns importantes grupos econômicos ligados ao setor açucareiro, em geral vinculados uns aos outros por laços familiares.

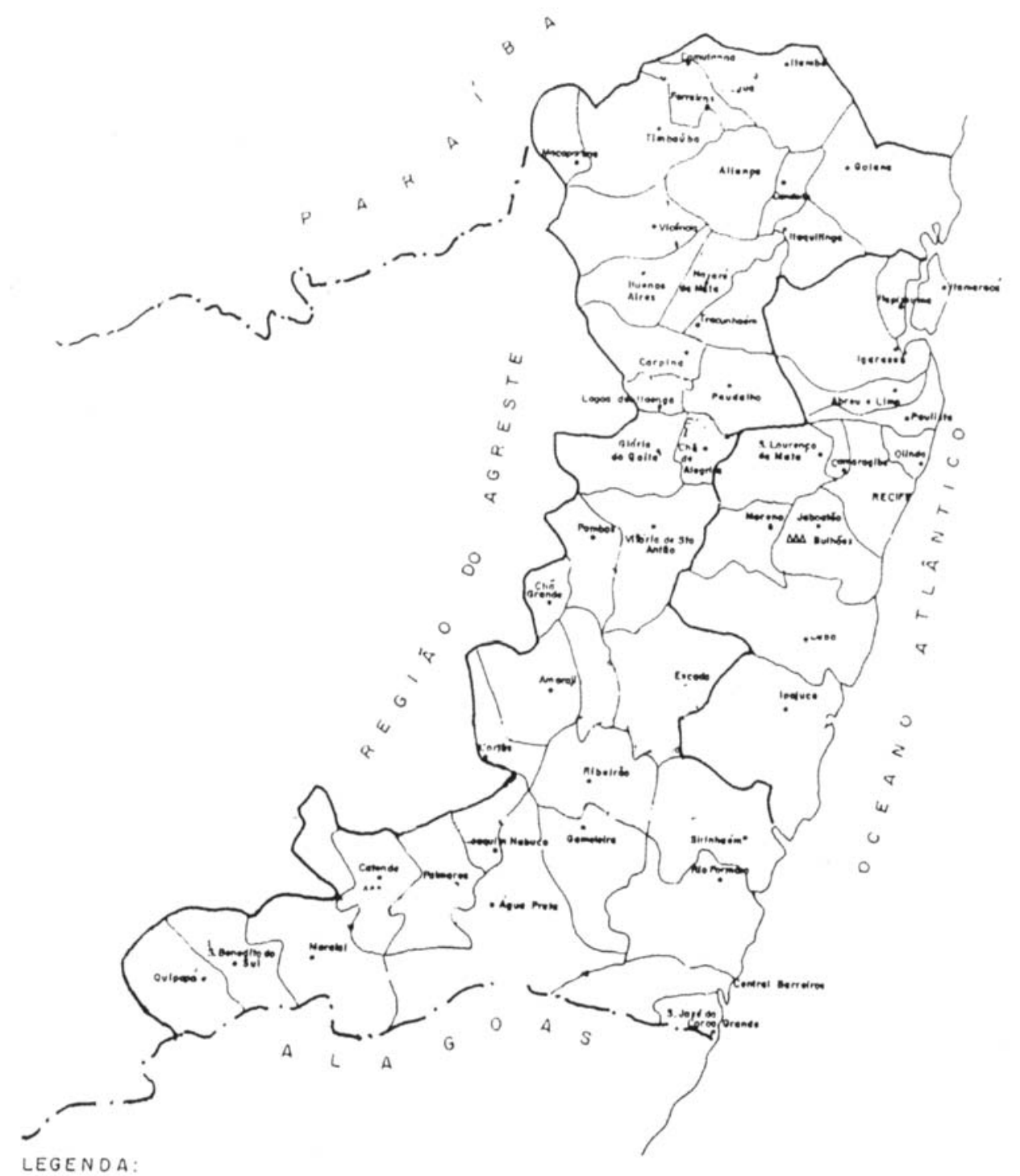

Figura 3 - Pernambuco: Usinas e destilarias

A realização de estudos sobre essas famílias seria relevante não só para pesquisar a trajetória de grupos econômicos do estado e as vinculações familiares existentes eles, mas também para analisar as relações existentes entre os industriais 
do açúcar e da indústria têxtil que se destacaram na primeira metade do século XX em Pernambuco, e o comércio exterior, a pecuária e a política. O relacionamento entre o comércio de exportação e engenho/usina era muito forte devido ao sistema de financiamento aos produtores pelos comerciantes - chamados de comissários - e que se apropriavam das usinas quando as dívidas se avantajavam, recebendo como pagamento de débitos várias usinas de açúcar, em seguida negociadas com grupos privados.

\section{A crise atual}

Pernambuco, no momento atual, enfrenta uma das maiores crises de sua história, devida a dois aspectos: o econômico e o natural. Como aspecto econômico, há o fechamento sucessivo de usinas e destilarias que encerraram as suas atividades ou porque o grupo econômico que controla algumas delas não dispõe de capital e de crédito suficientes, ou porque, prevendo a crise, algumas usinas transferiram os seus investimentos para outros setores econômicos ou para a própria indústria açucareira em outros estados, notadamente, Goiás, Mato Grosso, Mato Grosso do Sul e Minas Gerais. É acirrada também a concorrência de outros estados produtores, principalmente de São Paulo, frente às velhas agroindústrias açucareiras nordestinas e fluminenses. Além disso, a política do governo federal, com restrições de crédito, tem prejudicado a atuação das empresas nordestinas.

Quanto ao aspecto natural, o estado se depara com uma grande seca, que já se prolonga por vários anos. Apesar de prevista pelos institutos de pesquisa, ocorre sem que sejam tomadas precauções ou medidas preventivas por parte do governo federal e dos estados assolados, que se manifestam surpreendidos pela seca, e desenvolvem a velha política assistencialista, tradicional.

O fato vem gerando conseqüências negativas, uma vez que o encerramento das atividades de uma usina provoca forte impacto sobre a população trabalhadora, tanto agrícola quanto industrial, levando ao desemprego, à miséria e à fome grande parte da população. Em várias áreas, como na região da Mata meridional, o fechamento de usinas próximas umas das outras agravou consideravelmente as condições de vida da população, que passou a se concentrar nos centros urbanos. Não dispondo de qualificação profissional, assistência alimentícia, higiênica ou cultural, parte dela passa a viver de trabalhos ocasionais, de furto e de prostituição. Esta situação de miséria está provocando o ressurgimento de doenças que já haviam sido eliminadas desde o século XIX, sem falar na carência alimentar, que causa a degradação do homem e impede o desenvolvimento da cidadania.

O governo poderia ter aproveitado a ocasião da crise econômica que acarretou o fechamento das usinas para realizar uma reforma agrária autêntica, concentrando a cultura da cana em áreas ecologicamente mais favoráveis, como as várzeas e tabuleiros. Em alguns casos, terras poderiam ser recebidas como pagamento de dívidas de seus proprietários para com os bancos oficiais, nas quais 
poderiam ser desenvolvidas atividades empregadoras de mão-de-obra e tornarem-se rentáveis com a cultura de frutas e verduras, tanto para o abastecimento estadual quanto regional, ou até para a exportação. Poderia ainda ser ampliada a pecuária bovina semi-intensiva para a produção de leite e de carne. O estímulo à emigração deveria ser evitado, face à saturação do mercado de trabalho nas mais diversas áreas do país. Por outro lado, se houvesse maior preocupação com o ensino e a sua adequação às necessidades do mercado, poder-se-ia preparar mãode-obra qualificada, cada vez mais necessária.

O processo de ocupação das áreas dos antigos engenhos e usinas vem se dando de forma diversificada e as vezes conflituosa, como ocorreu recentemente na usina Aliança, no município do mesmo nome. Trabalhadores rurais sem terra, aliados a outros grupos e com o apoio da Pastoral da Terra, invadiram e depredaram as instalações industriais e a casa grande da usina, revoltados com a demora na efetivação da ação judiciária, informados de que se pretendia financiar proprietários e recuperar uma usina falida, em detrimento dos seus direitos.

Em geral, quando os novos proprietários são os antigos trabalhadores, vitoriosos nas questões trabalhistas, não tem havido conflitos de vez que a Justiça do Trabalho delimita, na sentença proferida, a área de cada novo proprietário o qual passa a cultivar a terra ou a vende a terceiros. Muitas vezes, para ter acesso ao mercado, eles se organizam em cooperativas.

No caso das invasões de terras improdutivas, estas ocorrem em duas fases: a que se segue à invasão, chamada de ocupação, e a seguinte, denominada de assentamento, quando as terras já foram desapropriadas e entregues aos agricultores. $\mathrm{O}$ período que intermedia as duas fases varia consideravelmente, conforme o andamento - mais ou menos lento - do processo de desapropriação. Analisandose o período entre 1989 e 1997 observa-se que o processo de invasões foi se intensificando, conforme dados apresentados no quadro 2. No início do ano 2000 observou-se na mesorregião assentamentos controlados pelo MST e pela FETAPE/ CONTAG (quadro 2).

Analisando-se tais dados, percebe-se como o processo de ocupação vem se intensificando, quer quanto ao número de ocupações quer quanto a quantidade de famílias nelas envolvidas. Em 1989 ocorreram apenas três ocupações envolvendo 500 famílias, enquanto em 1997, esta ocorrência foi de 51 ocupações incluindo 8.500 famílias. O número de famílias acampadas é inferior ao de famílias assentadas, como se observa ao comparar os dados de 1989 com os de 1997.

Os assentamentos distribuem-se por todo o território pernambucano, mas há um grande percentual deles na mesorregião da Mata, distribuídos pelos vários municípios, como consta dos quadros 3 e 4 .

Os dados apresentados indicam ainda ser pequeno o número de famílias em fases de ocupação ou de assentamento, face ao impacto da crise econômica e 
social que tem provocado intensificação do êxodo rural, sobrecarregando as cidades da região, sobretudo as do Grande Recife, com uma população não-qualificada para o trabalho urbano e com baixíssimos recursos a utilizar. Em conseqüência, podemos concluir que o problema urbano está intimamente ligado ao rural e dele é dependente.

Como o processo de ocupação de terras continua, a crise açucareira tende a se agravar, mesmo com a sua minimização no período 2000-2001 devida à elevação do preço do açúcar e à queda da produção do Centro-Sul.

Acreditamos que a economia da mesorregião da Mata Pernambucana tende a ser modificada, tanto com a diversificação da produção agrícola quanto com a formação na mesma de uma classe média rural, de pequenos e médios produtores que, unidos em cooperativas, vêm abrindo espaço para novos produtos voltados para os mercados local, regional e nacional, e até mesmo para o internacional. A melhor distribuição da renda feita em face da reorganização fundiária abre perspectivas para atividades terciárias nas diversas áreas e serviços.

Quadro 3

Áreas dos acampamentos coordenados pelo MST (1999)

\begin{tabular}{|c|c|c|}
\hline Municípios & $\begin{array}{c}N^{\circ} \text { de } \\
\text { propriedades }\end{array}$ & $\begin{array}{c}N^{\circ} \text { de familias } \\
\text { assentadas }\end{array}$ \\
\hline Amaraji & 4 & 155 \\
\hline Palmares & 2 & 180 \\
\hline Belém de Maria & 4 & 490 \\
\hline Joaquim Nabuco & 1 & 350 \\
\hline Tamandaré & 7 & 650 \\
\hline Escada & 6 & 590 \\
\hline Água Preta & 1 & 50 \\
\hline Catende & 1 & 80 \\
\hline Lagoa dos Gatos & 1 & 100 \\
\hline Xexeu & 1 & 70 \\
\hline Gameleira & 1 & 80 \\
\hline Barreiros & 3 & 150 \\
\hline São José da C. Grande & 1 & 70 \\
\hline Vicência & 3 & 102 \\
\hline Aliança & 8 & 528 \\
\hline Condado & 1 & 425 \\
\hline Itaquitinga & 01 & 150 \\
\hline Nazaré da Mata & 01 & 80 \\
\hline Total & 47 & 4.310 \\
\hline
\end{tabular}

Fonte: MST 
Quadro 2

Ocupação e assentamento de famílias em Pernambuco (1989-97)

\begin{tabular}{|c|c|c|c|c|}
\hline Ano & Ocupação & $\begin{array}{c}N^{\circ} \text { de famílias } \\
\text { acampadas }\end{array}$ & Assentamentos & $\begin{array}{c}N^{\circ} \text { de familias } \\
\text { assentadas }\end{array}$ \\
\hline 89 & 3 & 500 & - & - \\
\hline 90 & 5 & 300 & 2 & 42 \\
\hline 91 & 3 & 400 & 5 & 205 \\
\hline 92 & 9 & 1.250 & 1 & 135 \\
\hline 93 & 12 & 2.000 & 4 & 550 \\
\hline 94 & 15 & 2.500 & 5 & 720 \\
\hline 95 & 19 & 4.500 & 7 & 744 \\
\hline 96 & 35 & 3.500 & 17 & 1.320 \\
\hline 97 & 51 & 8.500 & 16 & 1.700 \\
\hline
\end{tabular}

Fonte: MST

Quadro 4

Áreas dos acampamentos coordenados pela FETAPE

\begin{tabular}{|l|c|c|}
\hline \multicolumn{1}{|c|}{ Municipios } & $\begin{array}{c}N^{\circ} \text { de } \\
\text { propriedades }\end{array}$ & $\begin{array}{c}N^{\circ} \text { de familias } \\
\text { acampadas }\end{array}$ \\
\hline Cortês & 01 & 37 \\
\hline Ipojuca & 03 & 86 \\
\hline Ribeirão & 03 & 1.028 \\
\hline Água Preta & 08 & 401 \\
\hline São Benedito do Sul & 01 & 33 \\
\hline Gameleira & 01 & 215 \\
\hline Amaraji & 01 & 42 \\
\hline Goiana & 02 & 76 \\
\hline Timbaúba & 01 & 180 \\
\hline Condado & 01 & 90 \\
\hline Itaquetinga & 01 & 16 \\
\hline Paudalho & 01 & 11 \\
\hline Vitória de Santo Antão & 02 & 40 \\
\hline Rio Formoso & 01 & 126 \\
\hline Tamandaré & 01 & -- \\
\hline TOTAL & 28 & 2.473 \\
\hline
\end{tabular}

Fonte: FETAPE 
Referências bibliográficas

ANDRADE, Manuel Correia de. Modernização e pobreza. A expansão da agroindústria canavieira e o seu impacto ecológico e social. São Paulo, Unesp, 1994.

A cana de açúcar e a mesorregião da Mata Pernambucana. Recife, Ed. Universitária, UFPE, 2001.

História das usinas de açúcar de Pernambuco. Recife, Ed. Massangana, 1989.

Modernização e pobreza. A expansão da agroindústria canavieira e o seu impacto ecológico e social. São Paulo, Unesp 1994.

AZEVEDO, João Lúcio. Épocas de Portugal econômico, 2. ed. Lisboa, Livraria Clássica Editora, 1947.

CARLI, Gileno de. Oprocesso histórico da usina em Pernambuco. Rio de Janeiro, Pongetti, 1942.

FREYRE, Gilberto. Nordeste: aspectos da influência da cana de açúcar na vida e na paisagem do Nordeste. Rio de Janeiro, José Olympio, 1937.

FURTADO, Celso. Formação econômica do Brasil. Rio de Janeiro, Fundo de Cultura, 1959.

PRADO JÚNIOR, Caio. Formação do Brasil contemporâneo. São Paulo, Martins, 1942.

Manuel Correia de Andrade, historiador, é pesquisador do Instituto Joaquim Nabuco e do Centro de Estudos e Pesquisas Josué de Castro, Recife.

A íntegra deste trabalho se encontra na Coleção Documentos, do IEA.USP. 